\title{
Looking Ahead-Future Issues when Reflecting on the Place of the iConsumer in Consumer Law and Copyright Law
}

\author{
Joris van Hoboken • Natali Helberger
}

Received: 29 October 2008 / Accepted: 6 November 2008 /

Published online: 3 December 2008

C The Author(s) 2008. This article is published with open access at Springerlink.com

\begin{abstract}
The following is a brief report of the discussion and main comments that were made during a workshop 'The place of the iConsumer in EU and US law-protecting consumers of copyright protected content', held in Amsterdam on 14 and 15 of December 2007. The workshop was part of a series of joint events organised by the Berkeley Centre for Law and Technology, University of California (BCLT) and the Institute for Information Law (IViR), University of Amsterdam on copyright and a follow-up to the conference on 'Copyright, digital rights management technology and consumer protection' that was held at the UC Berkeley in March 2007. The main goal of the workshop was to confront a consumer law approach with the more commonly discussed approach of internalising userrelated questions directly into copyright law. To this end, a selected group of European and US experts in both fields, copyright law and consumer law, were invited. The participants were then asked to share their thoughts and views from the different fields of law with regard to a number of main statements given by the organisers. The transatlantic perspective further added to the discussion. The main purpose of this report is to point to a number of issues that, according to the workshop participants, should be taken into account in future discussions concerning the legal position of the iConsumer. This report summarises the discussion along the three statements that the organisers asked participants to consider. The report gives some background information for each of the statements, to then describe the main arguments made during the workshop, to the extent that this discussion has not already been internalised in the papers that are part of this special JCP issue.
\end{abstract}

Keywords Consumer law · Copyright law · iConsumer · Digital content · Consumer right

J. van Hoboken $(\square) \cdot$ N. Helberger

Institute for Information Law (IViR), University of Amsterdam,

Rokin 84, 1012 KX Amsterdam, The Netherlands

e-mail: vanhoboken@ivir.nl

N. Helberger

e-mail: helberger@ivir.nl 


\section{Consumer Law, Rather than Copyright Law, is the Right Place to Accommodate the Interests of the iConsumer}

\section{Background}

As mentioned in the introduction to this special issue, there is a controversial discussion as to whether consumer law or copyright law is the right place to deal with the interests of iConsumers. Apart from making concrete suggestions of how to incorporate the interests of iConsumers into consumer law, respectively copyright law (Guibault 2008, this issue; Rott 2008, this issue; Schovsbo 2008, this issue), the discussion considered more generally arguments in favour and against the one or other approach.

\section{Discussion}

In the course of the discussion, a number of arguments in favour of a consumer law approach were considered. Some arguments were related to systematic particularities of copyright law itself, whilst others related to the characteristics of consumer law. Regarding the former, copyright law-systematic arguments, participants called attention for the fact that copyright law has traditionally focused on the interests of rightholders and authors, which would make the implementation of consumer rights into copyright law an upwards struggle for consumers, as opposed to consumer law where the interests of consumers are at the centre of attention. Another obstacle to the integration of consumer rights and interests into copyright law was, according to some participants, the tendency in European and US copyright law to conceptualise copyright law as property law. This would leave simply not much room for clear-cut and explicit consumer rights. Finally, it was feared that introducing iConsumer-concerns which are related to copyright to varying degrees into copyright law could lead to a system overload.

In contrast, consumer law could provide consumers with a clear set of rules that are better tailored to the needs of the iConsumer in an information economy. The information economy is a predominantly economic environment in which access to and use of digital content is a matter of commercial negotiations, the different business models and contractual agreements between consumers and service providers. Unlike copyright law, consumer law is designed to serve the interests of consumers, and accordingly, incorporates the consumer perspective. An example of the latter is the 'reasonable expectations test' in consumer sales law. Because consumer law regulates the relationship between businesses and consumers, a consumer law approach could allow tackling many of the iConsumers' concerns at their roots. Compared to copyright law, consumer law also has specific remedies and procedures for consumers to defend their legitimate interests in relation to suppliers. Finally, it was pointed out that the concerns of iConsumers are not necessarily confined to copyright law-related matters, but also included issues such as technical lock-in situations, information asymmetries, usage conditions, pricing issues, in other words: issues that are more at home in consumer law than in copyright law. This is why it was felt by many participants that a consumer law approach left more room for a more comprehensive treatment of all iConsumer-related concerns for the entire field of information law.

Having said this, the participants also pointed to a number of critical issues that should be taken into account in future discussions of a consumer law approach, for example, in the context of the review of the European consumer law acquis.

Before considering any intervention in either copyright or consumer law, it must be clear that market-based solutions are not equally or even more effective in accommodating the 
concerns of the iConsumer. One example that has been mentioned was the concept of 'measured consumption'. One participant explained that, whilst so-called digital rights management (DRM) technologies have been frequently condemned as inherently consumer-unfriendly, they can also support the creation of new business models that offer consumers more choice, convenience and usage experience. Much will depend on whether the industry is willing to explore such models, and when so doing, let themselves be guided by the interests and preferences of consumers. If consumer-friendliness were to become a distinctive factor in competition in information markets, the case for legal intervention would be less obvious.

When discussing proposals of how to adapt existing consumer law to the digital environment, ${ }^{1}$ some participants doubted whether the existing rules in consumer law that apply to tangible products could be simply extended to cover also intangible goods/ services. It was mentioned that this aspect also figured prominently in the review of the European Consumer Law acquis. Similarly, remedies that might be effective and useful in general consumer law might not necessarily serve the often more specific interests of consumers of digital content, respectively the public information policy considerations that govern this sector. Concerns were also voiced with regard to the scope of consumer law, notably of the definition of consumer. 'iConsumers' in the broadest sense also include libraries, teachers and journalists that are 'professionals' who probably fall outside the common definitions of 'consumer'. ${ }^{2}$ Also, Professor Swires' argument that digital consumers increasingly take over functions that were so far reserved to 'the other side', to professional suppliers, was confirmed by various participants.

There was general agreement that solutions that work for Europe are not necessarily similarly effective or appropriate in the US, and the other way round, because of differences in the legal systems. Participants from the US pointed out that the US copyright system left more room to accommodate the interests of the iConsumer than the author's right system that prevails in Europe. In the US, copyright law has a constitutional basis and has to serve some general public interest objectives, including the interests of consumers. For example, the heavy formality requirements in US law were said to have partly a consumer rationale. And numerous limitations and exceptions in US law were aimed at protecting the consumer (examples given were, e.g. the first sale doctrine and the provisions on the permissibility of the making of backup copies). Experts from the US argued that this was also a reason why some competent authorities in the US might object to dealing with iConsumer-related issues in consumer law. Authorities could argue that these issues have been dealt with already in copyright law. What is more, whilst consumer protection law in Europe was characterised by the participants as rather paternalistic, US participants explained that US consumer law

\footnotetext{
${ }^{1}$ One example discussed was adapting the Consumer Sales Directive (Directive 1999/44/EC of the European Parliament and of the Council of 25 May 1999 on certain aspects of the sale of consumer goods and associated guarantees ('Consumer Sales Directive'), OJ L 171/12 (07.07.1999)) to also cover digital services with the effect that the reasonable expectations of consumers who purchase intangible digital products and services would merit the same level of protection as the reasonable expectations of consumers of tangible products. Another example concerned more detailed transparency guidelines in order to overcome information asymmetries.

2 In the proposal for a directive on consumer law, it has been suggested to define "consumer" as "any natural person who, in contracts covered by this Directive, is acting for purposes which are outside his trade, business, craft or profession", Article 2 (1) of the Proposal for a Directive of the European Parliament and of the Council on consumer rights, Brussels, 8 October 2008, COM (2008) 614/3.
} 
tends to take the opposite stance: US consumer law has a strong focus on party autonomy and contractual freedom ('meeting of the minds'). US consumer law would, therefore, also respect the autonomy of consumers to make bad bargains. Partly, it was argued, this was also the result of the influence of the Chicago School in US law.

Finally, it was pointed out that solutions in copyright law and/or consumer law are not necessarily mutually exclusive. Some concerns of the iConsumer are related to (the scope of) copyright law itself (e.g. the permissibility of making digital private copies), whilst others are rather related to a copy of a protected work that cannot be used in ways that consumers expected when buying the copy. Whilst the former aspect is probably better regulated in copyright law, the latter question is rather a question of contracts and purchasing modalities. As such, it should be dealt with in consumer law. Accordingly, one of the conclusions from the workshop was that it is necessary to create functional interfaces between copyright law and consumer law, two areas of law that, so far, have been discussed separately and in different contexts.

\section{Within Consumer Law, a Sector-Specific, Still to be Designed iConsumer Tool is Probably the Most Appropriate Solution}

\section{Background}

One general point of critique of the consumer law approach is that consumer law has been designed to serve consumers in general, irrespective of the type and character of products and services they are using (Elkin-Koren 2007, pp. 1126-1129). This would not allow to take into account the particularities of digital content, the specific rights and freedoms that users enjoy with respect to digital content (freedom of expression, democratic freedoms, right to privacy) as well as the specific public policy objectives for this sector (cultural diversity, stimulation of creation, innovation and cultural exchange, bridging of the digital divide, accessibility and availability of digital content, to name but a few). This may explain why, the European Parliament has raised the question of whether the protection of consumers of digital content can be achieved by adapting existing consumer law or would call for one or more specific instruments (EP 2007).

Examples of consumer law and policy that are specifically geared to the information sector can be found in telecommunications law (and here, in particular, the Universal Service Directive) ${ }^{3}$ in e-commerce law ${ }^{4}$ or, more recently, in audiovisual law (Harcourt and Weatherill 2008, pp. 1-2). ${ }^{5}$ The recently amended Audiovisual Service Directive acknowledges that audiovisual content is not any longer broadcasted at an anonymous audience of passive receivers, but that digital technologies have triggered new, interactive

\footnotetext{
${ }^{3}$ Directive 2002/22/EC of the European Parliament and of the Council of 7 March 2002 on universal service and users' rights relating to electronic communications networks and services ('Universal Service Directive'), OJ L 108/51 (24.04.2002).

${ }^{4}$ Directive $2000 / 31 / \mathrm{EC}$ of the European Parliament and of the Council of 8 June 2000 on certain legal aspects of information society services, in particular, electronic commerce in the Internal Market ('ECommerce Directive'), OJ L 178/1 (17.07.2000).

${ }^{5}$ Directive 2007/65/EC of the European Parliament and of the Council of 11 December 2007 amending Council Directive $89 / 552 / \mathrm{EEC}$ on the coordination of certain provisions laid down by law, regulation or administrative action in Member States concerning the pursuit of television broadcasting activities ('Audiovisual Media Service Directive'), OJ L 332/27 (18.12.2007).
} 
business models such as on-demand services. With these new services, 'passive receivers' or citizens turn into consumers. In response, the directive has introduced new transparency obligations and amended its advertising provisions, to name but two examples (Helberger 2008, p. 128). The E-Commerce Directive is specifically aimed at consumers of so-called Information Society Services. One of its main goals is to provide for a high level of consumer protection whilst observing the specific needs and (fundamentally protected) interests of iConsumers, such as freedom of expression and the right to privacy (ECommerce Directive, recitals 9 and 14). The Universal Service Directive, finally, acknowledges that functioning competition is not only a matter of rules that ensure access to networks, facilities and functioning competition. Equally important is attention for possible contractual or technical lock-in situations in the terms of contracts of subscribers, information asymmetries or because of the lack of adequate interoperability solutions. Similarly than the consumer protection provisions in audiovisual and e-commerce law, the Universal Service Directive ${ }^{6}$ takes into account the specific needs and interests of the digital consumer (Universal Service Directive, recital 26 and Article 1).

The question that the organisers of the workshop submitted to the participants for discussion was whether, providing there are convincing arguments to protect the interests of iConsumers through the instruments of consumer law, should this be done in the context of general consumer law or within a new, still to be designed iConsumer Law.

\section{Discussion}

Participants emphasised repeatedly the need to take the perspective of the cultural landscape into account when thinking about regulating iConsumption. There was a general concern that consumer law would primarily deal with economic and individual consumers' considerations and here, in particular, the interest to read, watch or hear at an affordable price (but see Mak 2008, this issue). All participants agreed that it was equally important to also take into account the ability to make cultural, creative, democratic or innovative uses of digital content. The experts discussed some examples of issues that would probably not fit easily into a general consumer context: access to information, also for socially disadvantaged and consumers with impairments, the searchability of information and, more generally, special social/cultural consumption patterns with regard to digital content, the realisation of fundamental rights such as freedom of expression or the right to privacy, the relevancy of digital content for identity formation in the cultural space, the freedom of cultural production and cultural mobility, the freedom to enjoy works without surveillance, the freedom to enjoy information products in the space of choice and to share them with fellow citizens. It was felt that a sector-specific 'iConsumer law' might leave more room to consider the economic and public policy dimension of the problem. In this context, participants also agreed that valuable lessons could be learned from other fields of law, such as audiovisual, telecommunications or environmental law.

A critical element of such a (still to be designed) sector-specific iConsumer law would have to be a conception of the iConsumer that would represent a more holistic view of the consumer as consumer and citizen. Such a definition would need to acknowledge, on the one hand, that the involvement of consumers with digital content could go beyond its mere consumption. On the other hand, a definition of the iConsumer would need to take into

\footnotetext{
${ }^{6}$ Directive 2002/22/EC of the European Parliament and of the Council of 7 March 2002 on universal service and users' rights relating to electronic communications networks and services ('Universal Service Directive'), OJ L 108/51 (24.04.2002).
} 
account that semi-professional 'consumers' or even professionals with a certain mission (e.g. libraries, teachers or journalists) can require protection or support in their relationships with the information industry, as well. Experts also suggested the importance of provisions that would guarantee the effective participation of consumers and/or their representatives in decision- and law-making procedures. Other important aspects mentioned were remedies that take into account the specific needs of the iConsumer, as well as effective enforcement of their rights and corresponding monitoring procedures, for example, with the help of a specialised authority.

\section{The Adequate Protection of the iConsumer Requires Standardisation of Consumer Expectations}

\section{Background}

A major source of legal uncertainty in the discussion of the legal position of the iConsumer is the lack of guidance or of a common standard of what digital consumers can legitimately expect from digital products and services (Helberger and Hugenholtz 2007, pp. 10841089). Can, for example, a consumer expect to be able to make a certain number of private copies of a digital content or be able to play CDs on all technical devices of her choice? Arguably, the lack of a clear minimum standard of reasonable expectations weakens the negotiation position and legal standing of consumers in court proceedings. Accordingly, several attempts have been made to formulate more concrete digital consumer rights (Guibault 2008, this issue; Schovsbo 2008, this issue). ${ }^{7}$ The statement that the organisers of the conference asked the participants to discuss is whether, in their opinion, the adequate protection of the iConsumer required a certain formally accepted minimum standard of legitimate and protection-worthy consumer expectations with regard to digital content.

\section{Discussion}

Some participants argued that already the protection of fundamental rights and freedoms of consumers (e.g. freedom of expression, right to privacy) called for securing a certain minimum standard of reasonable expectations and rights of consumers with regard to digital content. Others drew attention to the fact that some degree of standardisation could be observed already, for example, in the form of standard form contracts or the information that businesses convey to consumers. Having said this, industry-driven forms of standardisation would not necessarily show sufficient respect for fundamental rights or the interests of consumers in general. Other participants argued against standardisation of consumer expectations. They suggested that information markets are in need of a flexible regulatory system, which would limit the possibilities of standardising consumer expectations. Due to technological and economic developments, and changing usage and consumption patterns, it was difficult, if not impossible, to draw up complete and coherent

\footnotetext{
${ }^{7}$ BEUC, "Declaration of Consumers' Digital Rights", online available at: http://www.consumersdigitalrights. org/cms/declaration_en.php; German Federal Ministry for Food, Agriculture and Consumer Protection, Consumer Protection Charter, online available at: http://www.bmelv.de/cln_045/nn_757130/EN/03ConsumerProtection/CharterDig.html_nnn=true; DigitalConsumer.org, The Consumer Technology Bill of Rights, online available at: http://www.digitalconsumer.org/.
} 
lists of consumer interests worthy of protection. Also, consumer interests were heterogeneous. Whilst it might be easier to reach agreement on some topics (e.g. the need to protect minors, transparency requirements), other interests were more controversial and did not lend themselves easily to standardisation (e.g. the number of private copies to be made or what contractual terms should be considered unfair or not). Mandatory lists with 'to-beguaranteed' consumer interests (e.g. the ability to make private copies) could be even disadvantageous to consumers as such requirements might discourage new business models and product differentiation. For example, services that stream digital content usually do not offer the possibility of making private copies. Yet, such services could be and already are very valuable for consumers. One expert mentioned that possible lessons could be learned from parallel discussions in standardising, e.g. technical specifications (Winn and Jondet 2008). One problem that was mentioned in the context of technical standardisation, which could also be relevant for the standardisation of consumer expectations, was the problem of keeping standards and lists accurate and timely. This task was deemed particularly challenging in a fast changing economic and technological environment, as the information economy is. There was much agreement among participants that critical to any attempts of standardisation is the need to pay attention to the institutional structures. Who can/should be entitled to develop standards and who should be involved in the process (e.g. participation of consumer representatives and civil society)? In this context, the example of the French DRM authority that Winn and Jondet described in their paper was discussed in more detail. Experts discussed the possibility of such an authority also in other jurisdictions and brought a number of arguments in favour and against the French approach. Arguments in favour of the French or a similar approach were, for example, the flexibility and expertise of a specialised authority and the possibility for consumers to seek a decision at low costs and within a reasonably short period of time. Another argument in favour that was made is that a specialised authority could create the necessary link between consumer and copyright law. Having said this, in order to be of real value to consumers, more attention should be paid to the composition and competencies of such an authority, the enforceability of its decisions and its relationships with courts.

Open Access This article is distributed under the terms of the Creative Commons Attribution Noncommercial License which permits any noncommercial use, distribution, and reproduction in any medium, provided the original author(s) and source are credited.

\section{References}

CEC (2007). Report on the outcome of the public consultation on the green paper on the review of the consumer acquis. Brussels: Commission of the European Communities Online available at http://ec. europa.eu/consumers/cons_int/safe_shop/acquis/acquis_working_doc.pdf.

Elkin-Koren, N. (2007). Making room for consumers under the DMCA. Berkeley Technology Law Journal, 22, 1119-1155 Online available at SSRN: http://papers.ssrn.com/sol3/papers.cfm?abstract_id=1024566.

EP (2007). Report on consumer confidence in the digital environment. Strasbourg: European Parliament, Committee on the Internal Market and Consumer Protection. A6-0191/207.

Guibault, L. (2008). Accomodating the needs of iConsumers: making sure they get their money's worth of digital entertainment. Journal of Consumer Policy. doi:10.1007/s10603-008-9080-7.

Harcourt, A., \& Weatherill, S. (2008). The Consumer, the European Union, and Media Law. Journal of Consumer Policy, 31, 1-4.

Helberger, N. (2008). From eyeball to creator - toying with audience empowerment in the Audiovisual Media Service Directive. Entertainment Law Review, 6, 128-145. 
Helberger, N., \& Hugenholtz, P. B. (2007). No place like home for making a copy: private copying in European copyright law and consumer law. Berkeley Technology Journal, 22, 1061-1098 Online available at SSRN: http://papers.ssrn.com/sol3/papers.cfm?abstract id=1012305.

Mak, C. (2008). Fundamental rights and the European regulation of iConsumer contracts. Journal of Consumer Policy. doi:10.1007/s10603-008-9084-3.

Rott, P. (2008). Download of copyright-protected internet content and the role of (consumer) contract law. Journal of Consumer Policy. doi:10.1007/s10603-008-9081-6.

Schovsbo, J. (2008). Integrating consumer rights into copyright law: a European perspective. Journal of Consumer Policy. doi:10.1007/s10603-008-9079-0.

Winn, J., \& Jondet, N. (2008). A "New Approach" to standards and consumer protection. Journal of Consumer Policy. doi:10.1007/s10603-008-9086-1. 